\title{
COMPARISON OF YIELD AND QUALITY OF RED BEET ROOTS CULTIVATED USING CONVENTIONAL, INTEGRATED AND ORGANIC METHOD
}

\author{
Anna A. SZOPIŃSKA ${ }^{1 *}$, Maria GAWĘDA ${ }^{2}$ \\ ${ }^{1}$ Rzeszów School of Engineering and Economics, Miłocińska 40, 35-232 Rzeszów, Poland \\ ${ }^{2}$ Department of Vegetable and Medicinal Plants, University of Agriculture in Krakow \\ al. 29 Listopada 54, 31-425 Kraków, Poland \\ Received: April 4, 2013; Accepted: July 2, 2013
}

\begin{abstract}
The experiment on different means of cultivation of red beet cv. 'Regulski Cylinder' was conducted in the years 2006-2009, using conventional, integrated, and organic methods. The greatest impact on total and commercial yield, the average root weight, dry weight and chemical constituents' content in the roots had the season. In the years 2006 and 2008, the highest total and marketable yields of beet roots were obtained by organic method, but in 2009 these parameters were the lowest in organically produced plants. Total yield was correlated with mean root weight. In the years 2006 and 2008, betanine content was the lowest in organically produced roots while in the year 2009 it was the highest. The low yield of marketable roots and the low nitrates' content were the only two parameters, which distinguished organically produced red beet roots throughout the years of experiment.
\end{abstract}

Key words: red beet, yielding, roots quality, organic cultivation, integrated cultivation, conventional cultivation

\section{INTRODUCTION}

Red beet (Beta vulgaris L.) is an important vegetable, which is on the fourth position in Poland in terms of production and consumption, after cabbage, carrot, and onion. Its cultivation does not cause any problems, and good storability ensures availability of fresh product year around without the need of applying expensive storage equipment. Red beets are also widely used in food industry. This generates farmers' interest, including those specialising in sustainable technologies of production. For many years, organic products received unflagging interest of consumers because of their pro health properties, which are due to their high content of minerals, vitamins, and pigments, i.e. compounds having beneficial effect on human organism (Szura et al. 2008, Zujko and Witkowska 2009, Hunter et al. 2011).
For health promoting activity of the red beets, the content of pigments in the roots is of a special importance. These pigments belong to two groups: red-violet betacyanins and yellow betaxantins. The betacyanins include betanine and isobetanine. Among betaxantins, the main position is occupied by vulgaxanthines (I and II). Betacyanins have been recently included to the group of natural plant antioxidants (Cai et al. 2003). It was demonstrated that all plant products containing betacyanins are characterised by high antioxidative potential. Among them is the red beet, which was recently included into the group of ten vegetables with the highest antioxidative potential. Pigments of the red beets, especially betanine, effectively inhibit lipid peroxidation and exhibit some anticarcinogenic, antibacterial and antiviral activity (Kanner et al. 2001). Red beets are the main source of betacyanins, used in food industry as natural dyes for food products (Szalaty 2008). Different redness 
shades of the root flesh are determined by the ratio of betacyanins to betaxantins, and their relative content depends on root size, variety, weather conditions during cultivation and fertilization (Felczyński and Elkner 2008).

The negative feature of red beets is a high tendency to accumulate nitrates, which after consumption may be converted in human intestines to carcinogenic nitrosamines. The presence of nitrates is a consequence of excessive nitrogen fertilization (Moćko and Wacławek 2005), however their accumulation may also occur even if the proper agrotechnique has been applied (Nabrzyski, Gajewska 1994).

The study aimed to determine the differences in the content of basic components determining quality of red beet roots cultivated using organic, integrated and conventional methods. Inconsistent results of numerous studies concerning quality of organic products with relation to products coming from other production systems justify the rightness of the undertaken study.

\section{MATERIAL AND METHODS}

Three methods of red beet 'Regulski Cylinder' cultivation were investigated: organic, integrated and conventional, during the years 2006, 2008, and 2009. All the experiments were performed in Wiśniowa, Podkarpackie Voivodship, on brown acidic soils with humus content ranging from 2.38 to $2.41 \%$. The treatment using organic method was conducted on a certified field. Integrated and conventional treatments were located on neighbouring fields in order to minimise variation resulting from different soil and climatic conditions.

Red beets were sowed in the third year after manure application. Potatoes cultivated on manure were used as the forecrop in the first year and cereals with a cover crop of legumes for autumn tillage in the second year. Additional supplementing fertilisation was applied in the spring, basing on results of soil analysis. In conventional and integrated methods it was done in a form of mineral fertilisers (nitrate, granular superphosphate and potassium salt) while in organic method in a form of liquid manure and certified fertilisers (phosphate rock powder). The nutrients in the soil were main- tained at the following levels: $\mathrm{N}-70 \mathrm{mg} \cdot \mathrm{dm}^{-3}, \mathrm{P}$ $60 \mathrm{mg} \cdot \mathrm{dm}^{-3}, \mathrm{~K}-150 \mathrm{mg} \cdot \mathrm{dm}^{-3}, \mathrm{Mg}-60 \mathrm{mg} \cdot \mathrm{dm}^{-3}, \mathrm{Ca}$ - $1500 \mathrm{mg} \cdot \mathrm{dm}^{-3}$. The cultivation of red beets, irrespective of the applied method, was conducted on low ridges with one-row sowing. At a stage of 2-4 true leaves, the thinning every $4-6 \mathrm{~cm}$ was applied.

In organic cultivation, mechanical weed control was applied. Before sowing, the seeds were dressed with soft soap. No pesticides controlling diseases were applied during the cultivation. Beet seeds for sowing in integrated and conventional technologies were primed with Thiram $75 \%$. The weed control was based on products approved for use in red beet cultivations. The first treatment with Lenacil $80 \%$ was carried out on broadleaf weeds 3 days after the sowing. The second treatment was performed on monocot weeds using Fluazifop-P-butyl $150 \mathrm{~g} \cdot \mathrm{dm}^{-3}$. The other weeding treatments in integrated method were conducted mechanically while in the conventional method, an additional application of herbicide Quizalofop-Pethyl $5 \%$ was used. In both integrated and conventional methods of cultivation, treatment against Cercospora beticola with Mankozeb $75 \%$ was applied at the first true leaf stage. No other plant protection treatment was used in both methods.

Directly after harvesting, the roots' weight, length, and diameter were measured along with the analysis of the dry matter content using ovendrying method at temperature $65^{\circ} \mathrm{C}$ as well as soluble sugars content with anthrone method (Yemm and Wills 1954), nitrates content using spectrophotometric method (PN-92/A-75112) and the content of ascorbic acid using iodate method (Samotus et al. 1982). The pigments of red beets betanine and vulgaxanthine - were determined according to Nilsson (1970).

In the presented study, each experimental object (cultivation method), was replicated four times, where the replication was $200 \mathrm{~m}^{2}$ plot. Obtained results were worked out with Statistica 8 software, using analysis of variance and NIR at a significance level of $\mathrm{p}=0.05$.

\section{RESULTS AND DISCUSSION}

Temperature and precipitation during the 3 years of the experiment varied significantly (Ta- 
ble 1). The year 2006 was the coldest, but with the highest temperature in July and September, as compared to other years. The mean temperature was the highest in 2008 and relatively uniform during the whole season, without low or high extremes. The year 2006 had the lowest total precipitation, with especially dry July but wet August. In May, July and September of 2008 precipitation was abundant. The season 2009 was most rainy, especially in May, June and July.

The total and marketable yields varied significantly between years (Table 2). In the years 2006 and 2008, the total and marketable yields of organically produced red beets were higher than those produced by conventional method. In the year 2009 in turn, the total and marketable yields of organically produced roots were the lowest when compared to the yields of conventionally produced red beets. Obtained results show a strong impact of conditions during vegetative season on the yield. When analysing mean yields from the three years of cultivation, no significant influence of cultivation method on the yield was noted. Marketable yield of the red beet roots cultivated in organic system constituted 88,74 and $71 \%$ of the total yield in the subsequent years in comparison to 83,100 and $93 \%$ in conventionally grown roots. Higher yield of organically produced red beets in the years 2006 and 2008 was reported also by Felczyński and Elkner (2008). On the contrary, Mäder et al. (1993) reported that yields of organically produced vegetables were by about $25 \%$ lower than of those produced conventionally. Yields of organically grown cabbage, carrot, onion, tomatoes, spinach and peas lower by $47-88 \%$ compared to integrated production, were reported by Fjelkner-Modig et al. (2000). It is generally believed that yields in organic agriculture are 10 $40 \%$ lower for a particular species when compared to the conventional one. The more intense the conventional agriculture and the higher its efficiency is, the greater is the difference (Kuś 2003). In Poland, considerably small differences in yielding of plants from organic and conventional cultivation are due to relatively extensive technology used in traditional farms, with low amounts of fertilisers and pesticides applied (Krasowicz 1996).
Marketable red beet roots from organic cultivation had lower mean weight in 2009 compared to the roots coming from conventional cultivation but higher than those produced according to integrated technology in the year 2006 (Table 3). Significantly lower mean weight of red beet roots cultivated using organic method is consistent with the results obtained by Mäder et al. (1993).

The roots of red beets cultivated using different methods did not differ in terms of dry matter content, while significant differences between years of cultivation were noted (Table 4). The lowest content of dry matter in all the treatments was noted in the year 2008, which was probably due to abundant precipitation in September. Lack of differences in dry matter content in roots of red beet produced in various technologies was reported by Sikora et al. (2010) and Mäder et al. (1993) and by Zarzyńska and Goliszewski (2006) for potatoes. Also Fjelkner-Modig et al. (2000) did not find any differences in dry matter content in onions produced by organic and integrated method, but they obtained higher dry matter content in organically cultivated peas, potatoes, carrots and tomatoes, while for cabbage the highest content of dry matter was noted in integrated production. Rossi et al. (2008) demonstrated that dry matter content in tomatoes coming from organic production was higher compared to these produced conventionally.

The content of nitrates in the roots varied depending on a cultivation method used and a year of cultivation. The lowest content was found in the roots coming from organic cultivation, while the highest in the roots from conventional one. The roots from integrated cultivation did not differ from the roots produced conventionally in terms of the trait discussed. Kosson et al. (2011) reported similar findings. Worthington (2001) concluded that nitrate's content in organic products is on average $15.1 \%$ lower as compared with traditionally produced ones. Zarzyńska and Goliszewski (2006) confirmed such a relationship for potatoes produced by organic and integrated methods. Comparing the nitrate's content in white and red cabbages, potatoes, lettuce, beets, parsley, carrots, celery, and Chinese cabbage from conventional and organic cultivation Rembiałkowska et al. (2012) concluded 
Table 1. Average monthly air temperature and precipitation at the experimental site

\begin{tabular}{|c|c|c|c|c|c|c|c|}
\hline Year of cultivation & April & May & June & July & August & September & Annual mean \\
\hline \multicolumn{8}{|c|}{ Temperature $\left({ }^{\circ} \mathrm{C}\right)$} \\
\hline 2006 & 9.4 & 13.5 & 17.0 & 21.3 & 18.3 & 15.5 & 8.7 \\
\hline 2008 & 9.3 & 13.6 & 18.0 & 18.7 & 18.9 & 13.0 & 9.6 \\
\hline 2009 & 11.1 & 13.3 & 16.6 & 20.0 & 18.8 & 15.2 & 9.0 \\
\hline \multicolumn{8}{|c|}{ Precipitation $(\mathrm{mm})$} \\
\hline 2006 & 38 & 106 & 91 & 16 & 104 & 25 & 612 \\
\hline 2008 & 46 & 105 & 87 & 118 & 55 & 103 & 736 \\
\hline 2009 & 4 & 103 & 146 & 98 & 45 & 32 & 773 \\
\hline
\end{tabular}

Table 2. Red beet yield depending on cultivation method

\begin{tabular}{lcccccccc}
\hline \multirow{2}{*}{$\begin{array}{c}\text { Method of } \\
\text { production }\end{array}$} & \multicolumn{3}{c}{ Total yield $\left(\mathrm{kg} \cdot 10^{-2} \mathrm{ha}^{-1}\right)$} & \multicolumn{3}{c}{$\begin{array}{c}\text { Marketable yield }\left(\mathrm{kg} \cdot 10^{-2} \mathrm{ha}^{-1}\right) \\
(\% \text { of total yield })\end{array}$} \\
\cline { 2 - 9 } & 2006 & 2008 & 2009 & $\begin{array}{c}\text { Mean for } \\
\text { the method }\end{array}$ & 2006 & 2008 & 2009 & $\begin{array}{c}\text { Mean for } \\
\text { the method }\end{array}$ \\
\hline Conventional & $16.14 \mathrm{a}^{*}$ & $10.32 \mathrm{a}$ & $33.13 \mathrm{~b}$ & $19.86 \mathrm{~ns} * *$ & $\begin{array}{c}13.39 \mathrm{a} \\
(83)\end{array}$ & $\begin{array}{c}10.32 \mathrm{a} \\
(100)\end{array}$ & $\begin{array}{c}30.97 \mathrm{~b} \\
(93)\end{array}$ & $\begin{array}{c}18.23 \mathrm{~ns} \\
(92)\end{array}$ \\
\hline Integrated & $29.42 \mathrm{~b}$ & $10.62 \mathrm{a}$ & $29.08 \mathrm{ab}$ & $23.04 \mathrm{~ns}$ & $\begin{array}{c}23.91 \mathrm{~b} \\
(81)\end{array}$ & $\begin{array}{c}10.50 \mathrm{a} \\
(99)\end{array}$ & $\begin{array}{c}26.94 \mathrm{~b} \\
(93)\end{array}$ & $\begin{array}{c}20.45 \mathrm{~ns} \\
(89)\end{array}$ \\
\hline Organic & $28.80 \mathrm{~b}$ & $24.85 \mathrm{~b}$ & $23.45 \mathrm{a}$ & $25.70 / \mathrm{s}$ & $\begin{array}{c}25.35 \mathrm{~b} \\
(88)\end{array}$ & $\begin{array}{c}18.45 \mathrm{~b} \\
(74)\end{array}$ & $\begin{array}{c}16.68 \mathrm{a} \\
(71)\end{array}$ & $\begin{array}{c}20.16 \mathrm{~ns} \\
(78)\end{array}$ \\
\hline Annual mean & $24.78 \mathrm{~b}$ & $15.26 \mathrm{a}$ & $28.55 \mathrm{~b}$ & & $\begin{array}{c}20.88 \mathrm{~b} \\
(84)\end{array}$ & $\begin{array}{c}13.09 \mathrm{a} \\
(86)\end{array}$ & $\begin{array}{c}24.86 \mathrm{~b} \\
(87)\end{array}$ & \\
\hline
\end{tabular}

* Means marked with the same letter within methods of cultivation and seasons do not differ significantly

$* * \mathrm{n} / \mathrm{s}$ - insignificant difference

Table 3. Parameters of red beet roots depending on cultivation method

\begin{tabular}{|c|c|c|c|c|c|c|c|c|c|c|c|c|}
\hline \multirow[b]{2}{*}{$\begin{array}{l}\text { Method of } \\
\text { production }\end{array}$} & \multicolumn{5}{|c|}{ Mean weight of marketable root $(\mathrm{g})$} & \multicolumn{3}{|c|}{ Root length $(\mathrm{cm})$} & & \multicolumn{3}{|c|}{ Root diameter $(\mathrm{cm})$} \\
\hline & 2006 & 2008 & 2009 & $\begin{array}{l}\text { Mean } \\
\text { for the } \\
\text { method }\end{array}$ & 2006 & 2008 & 2009 & $\begin{array}{l}\text { Mean } \\
\text { for the } \\
\text { method }\end{array}$ & 2006 & 2008 & 2009 & $\begin{array}{l}\text { Mean } \\
\text { for the } \\
\text { method }\end{array}$ \\
\hline $\begin{array}{l}\text { Conven- } \\
\text { tional }\end{array}$ & $\begin{array}{c}177.60 \\
a^{*} \\
\end{array}$ & $\begin{array}{c}159.93 \\
\mathrm{n} / \mathrm{s} * *\end{array}$ & $\begin{array}{c}269.62 \\
\mathrm{c} \\
\end{array}$ & $\begin{array}{c}202.38 \\
\mathrm{~b}\end{array}$ & $\begin{array}{c}16.27 \\
\mathrm{n} / \mathrm{s}\end{array}$ & $\begin{array}{c}11.77 \\
\mathrm{n} / \mathrm{s}\end{array}$ & $\begin{array}{c}18.47 \\
\mathrm{~b}\end{array}$ & $\begin{array}{c}15.50 \\
\mathrm{~b} \\
\end{array}$ & $\begin{array}{c}5.81 \\
\mathrm{ab} \\
\end{array}$ & $\begin{array}{c}5.99 \\
\mathrm{~b} \\
\end{array}$ & $\begin{array}{c}5.88 \\
\mathrm{~b}\end{array}$ & $\begin{array}{c}5.89 \\
b \\
\end{array}$ \\
\hline Integrated & $\begin{array}{c}278.92 \\
\mathrm{~b}\end{array}$ & $\begin{array}{c}134.98 \\
\mathrm{n} / \mathrm{s}\end{array}$ & $\begin{array}{c}181.65 \\
\mathrm{~b}\end{array}$ & $\begin{array}{c}198.52 \\
\mathrm{ab}\end{array}$ & $\begin{array}{c}16.07 \\
\mathrm{n} / \mathrm{s}\end{array}$ & $\begin{array}{c}12.59 \\
\mathrm{n} / \mathrm{s}\end{array}$ & $\begin{array}{c}16.75 \\
b\end{array}$ & $\begin{array}{c}15.14 \\
b\end{array}$ & $\begin{array}{c}6.00 \\
b\end{array}$ & $\begin{array}{c}5.14 \\
\mathrm{a}\end{array}$ & $\begin{array}{c}5.72 \\
b\end{array}$ & $\begin{array}{c}5.62 \\
b\end{array}$ \\
\hline Organic & $\begin{array}{c}212.09 \\
\mathrm{a}\end{array}$ & $\begin{array}{c}145.65 \\
\mathrm{n} / \mathrm{s}\end{array}$ & $\begin{array}{c}90.44 \\
\mathrm{a} \\
\end{array}$ & $\begin{array}{c}149.39 \\
\mathrm{a}\end{array}$ & $\begin{array}{c}16.75 \\
\mathrm{n} / \mathrm{s}\end{array}$ & $\begin{array}{c}12.70 \\
\mathrm{n} / \mathrm{s}\end{array}$ & $\begin{array}{c}9.66 \\
\mathrm{a} \\
\end{array}$ & $\begin{array}{c}13.03 \\
\mathrm{a} \\
\end{array}$ & $\begin{array}{c}5.43 \\
\mathrm{a} \\
\end{array}$ & $\begin{array}{c}5.43 \\
\mathrm{a}\end{array}$ & $\begin{array}{c}5.00 \\
\mathrm{a}\end{array}$ & $\begin{array}{c}5.29 \\
\mathrm{a}\end{array}$ \\
\hline $\begin{array}{l}\text { Annual } \\
\text { mean }\end{array}$ & $\begin{array}{c}222.87 \\
c\end{array}$ & $\begin{array}{c}146.85 \\
\mathrm{a}\end{array}$ & $\begin{array}{c}180.57 \\
b\end{array}$ & & $\begin{array}{c}16.36 \\
b\end{array}$ & $\begin{array}{c}12.35 \\
\mathrm{a}\end{array}$ & $\begin{array}{c}14.96 \\
b\end{array}$ & & $\begin{array}{c}5.75 \\
\mathrm{n} / \mathrm{s}\end{array}$ & $\begin{array}{c}5.52 \\
\mathrm{n} / \mathrm{s}\end{array}$ & $\begin{array}{c}5.53 \\
\mathrm{n} / \mathrm{s}\end{array}$ & \\
\hline
\end{tabular}

$*$,** for explanations see Table 2 . 
Table 4. Content of dry matter and nitrates in roots of red beet depending on cultivation method

\begin{tabular}{lcccccccc}
\hline \multirow{2}{*}{$\begin{array}{c}\text { Method of } \\
\text { production }\end{array}$} & 2006 & 2008 & 2009 & $\begin{array}{c}\text { Mean for } \\
\text { the method }\end{array}$ & 2006 & 2008 & 2009 & $\begin{array}{c}\text { Mean for } \\
\text { the method }\end{array}$ \\
\cline { 2 - 9 } Conventional & $14.45 \mathrm{ab} *$ & $13.15 \mathrm{~ns} * *$ & $14.06 \mathrm{a}$ & $13.88 \mathrm{~ns}$ & $3397 \mathrm{~b}$ & $2220 \mathrm{~ns}$ & $2827 \mathrm{~ns}$ & $2815 \mathrm{~b}$ \\
\hline Integrated & $14.64 \mathrm{~b}$ & $12.84 \mathrm{~ns}$ & $14.53 \mathrm{ab}$ & $14.00 \mathrm{~ns}$ & $3200 \mathrm{~b}$ & $1817 \mathrm{~ns}$ & $2770 \mathrm{~ns}$ & $2595 \mathrm{~b}$ \\
\hline Organic & $13.78 \mathrm{a}$ & $12.95 \mathrm{~ns}$ & $14.85 \mathrm{~b}$ & $13.86 \mathrm{~ns}$ & $1585 \mathrm{a}$ & $995 \mathrm{~ns}$ & $2275 \mathrm{~ns}$ & $1618 \mathrm{a}$ \\
\hline Annual mean & $14.29 \mathrm{~b}$ & $12.98 \mathrm{a}$ & $14.48 \mathrm{~b}$ & & $2727 \mathrm{~b}$ & $1677 \mathrm{a}$ & $2624 \mathrm{~b}$ & \\
\hline
\end{tabular}

*, ** for explanations see Table 2 .

Table 5. Content of sugars and ascorbic acid in roots of red beet depending on cultivation method

\begin{tabular}{lcccccccc}
\hline \multirow{2}{*}{ Method } & \multicolumn{4}{c}{ Soluble sugars (\% FM) } & \multicolumn{3}{c}{ Ascorbic acid (mg\%) } \\
\cline { 2 - 9 } & 2006 & 2008 & 2009 & $\begin{array}{c}\text { Mean for } \\
\text { the method }\end{array}$ & 2006 & 2008 & 2009 & $\begin{array}{c}\text { Mean for } \\
\text { the method }\end{array}$ \\
\hline Conventional & $8.28 \mathrm{~ns} * *$ & $6.98 \mathrm{~ns}$ & $7.43 \mathrm{ab}^{*}$ & $7.57 \mathrm{~ns}$ & $6.24 \mathrm{~b}$ & $7.81 \mathrm{~b}$ & $9.46 \mathrm{c}$ & $7.83 \mathrm{~b}$ \\
\hline Integrated & $8.51 \mathrm{~ns}$ & $6.76 \mathrm{~ns}$ & $6.54 \mathrm{a}$ & $7.27 \mathrm{~ns}$ & $5.06 \mathrm{a}$ & $7.01 \mathrm{a}$ & $8.25 \mathrm{~b}$ & $6.77 \mathrm{ab}$ \\
\hline Organic & $8.16 \mathrm{~ns}$ & $7.61 \mathrm{~ns}$ & $8.13 \mathrm{~b}$ & $7.97 \mathrm{~ns}$ & $5.44 \mathrm{a}$ & $7.59 \mathrm{ab}$ & $6.71 \mathrm{a}$ & $6.58 \mathrm{a}$ \\
\hline Annual mean & $8.32 \mathrm{~b}$ & $7.12 \mathrm{a}$ & $7.37 \mathrm{a}$ & & $5.58 \mathrm{a}$ & $7.47 \mathrm{~b}$ & $8.14 \mathrm{~b}$ & \\
\hline
\end{tabular}

*,** for explanations see Table 2 .

Table 6. Content of pigments on roots of red beet depending on cultivation method

\begin{tabular}{|c|c|c|c|c|c|c|c|c|c|c|c|c|}
\hline \multirow[b]{2}{*}{ Method } & \multicolumn{4}{|c|}{$\begin{array}{c}\text { Betanine } \\
(\% \mathrm{FM})\end{array}$} & \multicolumn{4}{|c|}{$\begin{array}{c}\text { Vulgaxanthine } \\
(\% \mathrm{FM})\end{array}$} & \multicolumn{4}{|c|}{$\begin{array}{l}\text { Ratio of betanine } \\
\text { to vulgaxanthine }\end{array}$} \\
\hline & 2006 & 2008 & 2009 & $\begin{array}{l}\text { Mean } \\
\text { for the } \\
\text { method }\end{array}$ & 2006 & 2008 & 2009 & $\begin{array}{l}\text { Mean } \\
\text { for the } \\
\text { method }\end{array}$ & 2006 & 2008 & 2009 & $\begin{array}{l}\text { Mean } \\
\text { for the } \\
\text { method }\end{array}$ \\
\hline \multirow{2}{*}{ Conventional } & 0.529 & 0.499 & 0.306 & 0.445 & 0.321 & 0.168 & 0.129 & 0.271 & 1.65 & 2.97 & 2.37 & 2.33 \\
\hline & $\mathrm{b}$ & $\mathrm{c}$ & $\mathrm{a}$ & $\mathrm{n} / \mathrm{s}$ & $\mathrm{n} / \mathrm{s}$ & $\mathrm{n} / \mathrm{s}$ & $\mathrm{b}$ & $\mathrm{b}$ & $\mathrm{n} / \mathrm{s}$ & $\mathrm{a}$ & $\mathrm{n} / \mathrm{s}$ & $\mathrm{a}$ \\
\hline \multirow{2}{*}{ Integrated } & 0.564 & 0.433 & 0.292 & 0.430 & 0.282 & 0.124 & 0.081 & 0.162 & 2.00 & 3.49 & 3.60 & 3.03 \\
\hline & $\mathrm{b}$ & $\mathrm{b}$ & $\mathrm{a}$ & $\mathrm{n} / \mathrm{s}$ & $\mathrm{n} / \mathrm{s}$ & $\mathrm{n} / \mathrm{s}$ & $\mathrm{a}$ & $a b$ & $\mathrm{n} / \mathrm{s}$ & $\mathrm{a}$ & $\mathrm{n} / \mathrm{s}$ & $\mathrm{a}$ \\
\hline \multirow{2}{*}{ Organic } & 0.394 & 0.376 & 0.439 & 0.403 & 0.141 & 0.059 & 0.132 & 0.111 & 2.79 & 6.37 & 3.32 & \\
\hline & $\mathrm{a}$ & $\mathrm{a}$ & $\mathrm{b}$ & $\mathrm{n} / \mathrm{s}$ & $\mathrm{n} / \mathrm{s}$ & $\mathrm{n} / \mathrm{s}$ & $\mathrm{ab}$ & $\mathrm{a}$ & $\mathrm{n} / \mathrm{s}$ & $\mathrm{b}$ & $\mathrm{n} / \mathrm{s}$ & $4.10 \mathrm{~b}$ \\
\hline \multirow{2}{*}{ Annual mean } & 0.496 & 0.436 & 0.346 & & 0.248 & 0.117 & 0.171 & & 2.15 & 4.28 & 3.10 & \\
\hline & $\mathrm{b}$ & $\mathrm{b}$ & $\mathrm{a}$ & & $\mathrm{n} / \mathrm{s}$ & $\mathrm{n} / \mathrm{s}$ & $\mathrm{n} / \mathrm{s}$ & & $\mathrm{a}$ & $\mathrm{b}$ & $\mathrm{a}$ & \\
\hline
\end{tabular}

$*, * *$ for explanations see Table 2 .

that it was higher by $148.39 \%$ on average in conventionally produced vegetables than in those coming from organic cultivation. In our experiment, the highest differences in nitrate's content were between years of cultivation. They were high in 2006 and 2009, which coincides with high temperature and low precipitation in September. Drought increases the nitrate's content by inhibiting their reduction in plant tissues. An impact of cultivation method, climatic conditions, and genotype on nitrates content in roots of red beets was discussed by Mäder et al. (1993). Several authors reported influence of the form and amount of fertilizer used, weather conditions, soil type, cultivation and genetic factors (Michalik and Grzebelus 1995, Rożek 2000, Felczyński and Elkner 2008). Felczyński and Elkner (2008) reported that at lower levels of manure fertilization an additional 
fertilization with mineral nitrogen increased the level of nitrates in beet roots. Szura et al. (2008) noted lower level of nitrates in red beets in cooler summers, when fertilizers with reduced forms of nitrogen $\left(\mathrm{NH}_{4}{ }^{+}\right)$and fertilizers containing nitrification inhibitors (CULTAN method) were used. Soil $\mathrm{pH}$ is of a big importance for the accumulation of nitrates in plants. Maintenance of $\mathrm{pH}$ level at 6.57.5 is one of the factors necessary to reduce $\mathrm{NO}_{3}{ }^{-}$ content in vegetables (Sady 2000). Usually, high accumulation of nitrates in red beet roots coming from integrated and conventional cultivation can be explained both by excessive nitrogen uptake from the applied mineral fertilizers and by lower range of soil $\mathrm{pH}$.

The soluble sugars content in organically produced roots was significantly higher than in roots coming from the other systems only in 2009 (Table 5). The lack of differences in sugars content in roots of red beets originating from different cultivation technologies was also noted by Mäder et al. (1993), Sikora et al. (2010) and Kazimierczak et al. (2011). Hallmann (2012) showed an increase in the total content of sugars and in a higher sugar to organic acids ratio in organic tomatoes when compared to these produced conventionally. Rembiałkowska et al. (2012) confirmed a higher content of total sugars in organic fruits and vegetables, including carrots, beets, potatoes, spinach, kale, cherries, black currants and apples, which contributes to an increase in the technological and sensory quality (taste) of organic products. It is due to the sustainable management based on organic fertilizers, which are decomposed slowly by soil microorganisms and are gradually being made available for uptake by plants. Higher levels of easily available nitrogen in the conventional crops lead to the increased synthesis of amino acids and proteins, which inhibits the synthesis of carbon-reach compounds, including carbohydrates (Worthington 2001).

Ascorbic acid content depended significantly on the method and year of cultivation (Table 5). In each year, the lowest amounts were noted in roots coming from organic production, while in roots from conventional cultivation its level was the highest in each year of the study. Higher content of ascorbic acid was noted in years 2008 and 2009, as compared to year 2006.

Reports on effect of the cultivation method on vitamin content are inconclusive. The lower content of vitamin $\mathrm{C}$ in the roots originating from organic cultivation as compared to roots from conventional cultivation was noted by Sikora et al. (2010), whereas Worthington (2001) reported that vitamin C content was on average $27 \%$ higher in organically grown vegetables when compared to conventional ones, with the exception of carrots. On the other hand, Kazimierczak et al. (2011) and Mäder et al. (1993) found no difference in vitamin $\mathrm{C}$ content in the red beet roots from different cropping systems and the same was observed by Fjelkner-Modig et al. (2000) in cabbage, onion, peas and tomatoes cultivated using organic and integrated methods. Hunter (2011) showed an increase in vitamin $\mathrm{C}$ content in organically grown carrots and potatoes. Higher level of ascorbic acid in organic potatoes and tomatoes was observed by Solarska et al. (2010); however there were no differences in case of carrots, red beets and leek. Brandt et al. (2011) compared the results of several studies and concluded that there is a tendency to higher levels of vitamin $\mathrm{C}$ in organic products.

The lowest content of betanine was determined in organically produced beet roots in the years 2006 and 2008, but in 2009 the organic roots had the highest content of this compound (Table 6). The content of the vulgaxanthine did not depend on the cultivation method or the year of cultivation. The only difference concerning higher content of this compound in conventionally grown beet root was recorded in 2009 .

The ratio of betanine to vulgaxanthine ranged from 2.40 to 4.32 , and was significantly higher in organic beets only in 2008. Higher betanine to vulgaxanthine ratio in flesh of organic red beets as compared to red beets coming from other cultivations was observed by Felczyński and Elkner (2008). They obtained the highest content of betanine and the highest ratio of betanine to vulgaxanthine using low doses of fertiliser $\left(\mathrm{N}-60, \mathrm{P}_{2} \mathrm{O}_{5}-30\right.$, $\mathrm{K}_{2} \mathrm{O}-70 \mathrm{~kg} \cdot \mathrm{ha}^{-1}$ ), achieving concurrently high marketable yields of well-coloured roots. Kosson et al. (2011) confirmed the higher content of betanine in 
organic beet roots when compared to conventional ones and showed that its level depends on weather conditions at the time of planting, fertilization and plant genotype.

The results obtained in our experiment show that yield, dry matter and soluble sugars' content of red beet roots produced in organic, integrated and traditional technology do not differ significantly. However, organically grown red beets had smaller root diameter and length, which resulted in a smaller share of marketable roots when compared to red beets produced using conventional method. They were also characterised by a lower level of nitrates and ascorbic acid and by a higher betanine to vulgaxanthine ratio (in one year only) when compared to red beets coming from integrated and conventional production.

\section{REFERENCES}

Cai Y., Sun M., Corke H. 2003 Antioxidantactivity of betalains from plants of the Amaranthaceae. J. Agri. Food Chem. 51: 2288-2294.

Brandt K., Leifert C., Sanderson R., Seal C.J. 2011. Agroecosystem management and nutritional quality of plant foods: The case of organic fruit and vegetables. Cr. Rev. Plant Sci., 30: 177-198.

Felczyński K., Elkner K. 2008. Effect of long-term organic and mineral fertilization on the yield and quality of red beet (Beta vulgaris L.). Veget. Crops Res. Bull. 68: 111-125. DOI: 10.2478/v10032-0080010-7

Fjelkner-Modig S., Bengtsson H., Stegmark R., and Nyström S. 2000. The influence of organic and integrated production on nutritional, sensory and agricultural aspects of vegetable raw materials for food production. Acta Agric. Scand., Sect B, Soil Plant Sci. 50: 102-113.

Hallmann E. 2012. The influence of organic and conventional cultivation systems on the nutritional value and content of bioactive compounds in selected tomato types. J. Sci. Food Agric. 92: 28402848.

Hunter D., Foster M., McArthur J. O., Ojha R., Petocz P., Samman S. 2011. Evaluation of the micronutrient composition of plant foods produced by organic and conventional agricultural methods. Cr. Rev. Food Sci. Nutr. 51: 571-582.
Kanner J., Harel S., Granit R. 2001. Betalains - a new class of cationized antioxidants. J. Agric. Food Chem., 49: 5178-5185.

Kazimierczak R., Hellmamm E., Treščinska V., Rembiałkowska E. 2011. Estimation of the nutritive value of two red beet (Beta vulgaris) varieties from organic and conventional cultivation. Journal of Research and Applications in Agricultural Engineering 56 (3): 206-210.

Kosson R., Elkner K., Szafirowska A. 2011. Quality of fresh and processed red beet from organic and conventional cultivation. Veget. Crops Res. Bull. 75: 125-132. DOI: 10.2478/v10032-011-0024-4.

Krasowicz S. 1996. Analysis and assessment of ecological integrated and traditional agricultural holdings on the area of north-eastern Poland on the background of natural and economicorganisational conditions. IUNG Puławy, ser. H: 11. [in Polish with English abstract]

Kuś J. 2003. Yielding of selected crops in different crop production systems. Zesz. Nauk. AR w Krakowie 399 (89): 7-17.

Mäder P., Pfiffner L., Niggli U., Balzer U., BAlzer F., Besson J-M., Plochberger, Velimirov A. and Boltzmann L. 1993. Effect of three farming systems (bio-dynamic, bio-organic, conventional) on yield and quality of beetroot (Beta vulgaris L. var. esculenta L.) in a seven year crop rotation. Acta Hort. 339: 11-31.

Michalik B., Grzebelus D. 1995. Betanine and nitrate contents in table beet cultivars as a function of growth period and manner of nitrogen fertilization. Acta Hort. 379. 205-212.

Moćko A., Wacławek W. 2005. Assessment of heavy metals and nitrates (III) and (V) content in selected vegetable species from allotment gardens in Ozimek city. Bromat. Chem. Toksykol. 38 (1): 41 46. [in Polish with English abstract]

Nabrzyski M., Gajewska R. 1994. Content of nitrates and nitrites in fruits and vegetables and some other food products. Roczn. PZH, 45(3): 167-180. [in Polish with English summary]

Nilsson T. 1970. Studies into the pigments in beetroot (Beta vulgaris L. ssp. vulgaris var. rubra L.). Lantbrukshögsk Ann. 36: 179-197.

PN-92/A-75112. 1992. Owoce, warzywa i ich przetwory. Oznaczanie zawartości azotanów i azotynów.

Rossi F., Godani F., Bertuzzi T., Trevisan M., Ferrari F. and Gatti S. 2008. Health - promoting substances and heavy metal content in tomatoes grown with different farming techniques. Eur. J. Nutr. 47: 266-272. 
Rembiałkowska E., Załęcka A., Badowski M., Ploeger A. 2012. The Quality of Organically Produced Food. http://dx.doi.org/10.5772/54525 p. 65-93.

Rożek S. 2000. Factors influencing nitrates accumulation in vegetables yield. Zesz. Nauk. AR w Krakowie 364: 19-31.

Sady W. 2000. Nawożenie warzyw polowych. Wydawnictwo PLANTPRESS. Kraków: 47-52.

Samotus B., Leja M., Ścigalski A. 1982. A comparison of four methods of determination of ascorbic acid in fruits and vegetables Acta Agr. Silv., ser. Agr. 21: 105-121. [in Polish with English abstract]

Sikora M., Klonowska K., Hallmann E., Rembiałkowska E. 2010. Nutritive quality of red beet roots from organic and conventional production. In: Rembiałkowska E. (ed.), The impact of organic production methods on the vegetable product quality. Published by SGGW, Warszawa, Poland, pp. 209-220.

Solarska E., Hallmann E., Rembiałkowska E., Szymona J. 2010. A nutritional value of selected vegetables fertilised with compost and synthetic mineral fertilizers. In: Rembiałkowska E., (ed.), The impact of organic production methods on the vegetable product quality. Published by SGGW, Warszawa, Poland, pp. 221-229.

Szalaty M. 2008. Physiological roles and bioavailability of betacyanins. Post. Fit. 1: 20-25.

Szura A., Kowalska I., Sady W. 2008. Biological value of red beets in relation to nitrogen fertilization. Veget. Crops Res. Bull. 68: 145-153. DOI: 10.2478/v10032-008-0013-4

Worthington V. 2001. Nutritional quality of organic versus conventional fruits, vegetables, and grains. J. Alter. Compl. Med. 7 (2): 161-173.

Yemm E.W., Wills A.J. 1954. The estimation of carbohydrates in plant extracts by anthrone. Biochem. J. 54: 508-514.

Zarzyńska K., Goliszewski W. 2006. Potato production in organic and integrated system and tuber quality. Pamiętnik Puławski 142: 617-626. [in Polish with English abstract]

Zujko M. E., Witkowska A. 2009. Antioxidant activity popular species fruits, vegetables, mushrooms and pulsem. Bromat. Chem. Toksykol. 3: 895-899. 